\title{
Isolated Giant Hydatid Cyst in Kidney
}

\author{
Böbrekte İzole Dev Kist Hidatik
}

\author{
Faruk Özgör, Akif Erbin, Ahmet Yalçın Berberoğlu, Murat Binbay, Ömer Sarılar, \\ Ahmet Yaser Müslümanoğlu
}

Haseki Training and Research Hospital, Clinic of Urology, İstanbul, Turkey

\begin{abstract}
Cyst hydatid of the kidney is parasitic condition caused by Echinococcus granulosus and identified in many countries, especially associated with sheep farming. Echinococcal larvae enter the bloodstream using the digestive system and invade any organs in the human body. The urinary system is the third most common area affected by parasitic infection after liver and lungs, but isolated renal involvement is a very rare situation, even in endemic areas. In our case, we aimed to report a 57-year-old female patient with an 18-centimeter isolated renal cyst hydatid treated by retroperitoneal nephrectomy. The diagnosis was based on imaging findings and confirmed by histopathologically. (Turkiye Parazitol Derg 2014; 38: 124-6)
\end{abstract}

Key Words: Echinococcus granulosus, cyst hydatid, parasitic infections

Received: 07.02.2013

Accepted: 22.07.2013

\section{ÖZET}

Böbrek kist hidatiği Echinococcus granulosus tarafından oluşturulan parazitik bir hastalıktır ve özellikle koyun yetiştiriciliğinin olduğu birçok ülkede görülür. Ekinokok larvaları sindirim sistemini kullanarak kan dolaşımına girer ve insan vücudunda herhangi bir organı tutabilir. Üriner sistem tutulumu karaciğer ve akciğerlerden sonra en sık tutulan bölgedir ama izole böbrek tutulumu endemik bölgelerde bile çok nadir görülür. Vakamızda 18 santimetre boyutunda izole renal kist hidatik tutulumu olan ve retroperitoneal olarak nefrektomi yapılan 57 yaşında bayan hastayı sunmayı amaçladık. Tanıya görüntüleme yöntemlerine dayanılarak ulaşıldı ve histopatolojik olarak doğruluğu desteklendi. (Turkiye Parazitol Derg 2014; 38: 124-6)

Anahtar Sözcükler: Ekinokokkus granulosus, kist hidatik, parazitik infeksiyonlar

Geliş Tarihi: 07.02.2013

Kabul Tarihi: 22.07.2013

\section{INTRODUCTION}

Although we are in the age of antibiotics, parasitic infections continue to be a reason of serious health problems. Echinococcosis, also known as hydatid disease, is endemic trouble in many parts of the world caused by infection with a larval form of parasitic tapeworm Echinococcus granulosus (1). Dogs are typically a definitive host, and many herbiv- orous livestock creatures-called intermediate hosts-contain parasites in intestines and are also sources for transmission to human. Humans are accidental hosts for echinococcus, and foods contaminated by eggs of the parasite play a role in transition. After the entry of embryos (oncosphere) into the bloodstream, the oncosphere could invade various organs and develop into a hydatid cyst (2-3). Kidney is the third most common organ involved after the liver (75\%) and the

Address for Correspondence / Yazışma Adresi: Dr. Faruk Özgör, Haseki Training and Research Hospital, Clinic of Urology, İstanbul, Turkey. Phone: +90 5367286312 E-mail:md.farukozgor@yahoo.com DOI:10.5152/tpd.2014.3081

CCopyright 2014 Turkish Society for Parasitology - Available online at www.tparazitolderg.org

(CTelif hakkı 2014 Türkiye Parazitoloji Derneği - Makale metnine www.tparazitolderg.org web sayfasından ulaşılabilir. 
lungs (15\%), but isolated renal involvement is a rare condition, with a $2 \%$ incidence (4). Also, different clinical manifestations of the disease cause difficulties for diagnosis. In this report, we aim to present a patient with isolated renal hydatid cyst $(\mathrm{RCH})$.

\section{CASE REPORT}

A 57-year-old obese (BMI: $32.2 \mathrm{~kg} / \mathrm{m}^{2}$ ) female patient was admitted to the hospital with asthenia, intermittent hematuria, and left flank pain of 14 months in duration. She had a history of uncontrolled hypertension without using any drug. In the physical examination, there were no pathological findings. Complete blood count and biochemical tests, including creatinine and electrolytes, were at normal levels. Urine analyses and chest graphy showed no abnormalities, but abdominal ultrasonography presented a cystic lesion, including a solid area in the left kidney and suspected renal cancer. Computed tomography revealed an 18-centimeter heterogeneous and multivesicular cyst with calcified wall; also, daughter cysts were described (Figure 1). The giant cyst had a deteriorated renal parenchyma, and because of its size, open total nephrectomy was indicated and performed. Operation was performed with a left flank incision. Cystic fluid was aspirated to facilitate control of the renal vessels and obtain lower intracystic pressure. Surrounding tissues were protected by using hypertonic 20\% saline packs. Operation time was 105 minutes, and estimated blood loss was $110 \mathrm{cc}$. No complications occurred. The post-operative period was uneventful, and the patient was discharged 2 days after the operation. The histopathological findings confirmed the diagnosis (Figure 2). The patient received $10 \mathrm{mg} / \mathrm{kg}$ albendazol for 1 week preoperatively and for 3 weeks postoperatively.

\section{DISCUSSION}

Renal echinococcosis, or hydatid cyst of the kidney, is an acquired disease caused by echinococcus parasites. Echinococcus (E. granulosus, E. multilocularis, and E. rarer) are flatworm belonging to the order cestoda and the tenia family (5). Adult forms of parasites live in the bowel of dogs or foxes, and sheep are intermediate hosts. Accordingly, echinococcal disease continues to be endemic in sheep-raising countries, such as Algeria, Tunisia, Australia, Egypt, and Canada (6). Humans get eggs of parasites from contaminated foods and water, thus accidentally taking the place as intermediate host in the parasitic cycle. The embryos migrate into the duodenum wall and enter the circulation system. Liver and lungs are the two most common organs involved by echinococcus. Hydatid cyst of the urinary system has been seen in $4 \%$ of all cases, and kidney is the most commonly affected organ. In addition, involvement of the vesiculoseminalis, bladder, prostate, and spermatic cord have been seen in various case reports (7).

Generally, there are no specific symptoms or indications to diagnose $\mathrm{RCH}$. The disease usually continues asymptomatically for years and is then discovered incidentally. Flank pain, fever, intermittent hematuria, dyspepsia, abdominal distension, vomiting, and weight loss are the most common symptoms (8). Rarely, palpable mass is determined in the physical examination. Only hydaturia-grabe like material in urine is a pathognomonic sign and reveals with rupture of the cystic lesion into the collecting system. Hydaturia is uncommon and has been reported in 5\%-

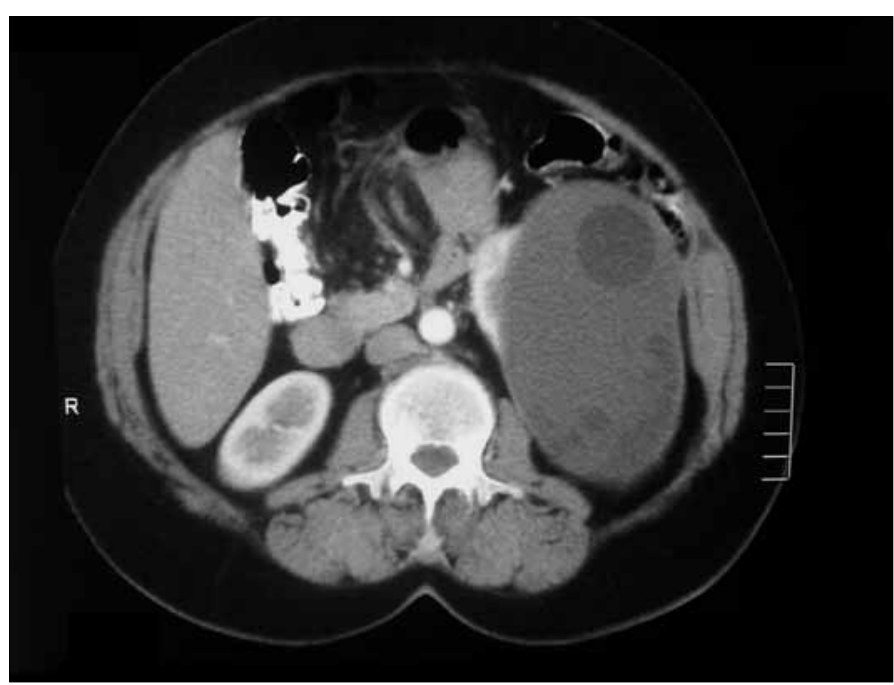

Figure 1. Cyst hydatid in left kidney in 18 centimeter size

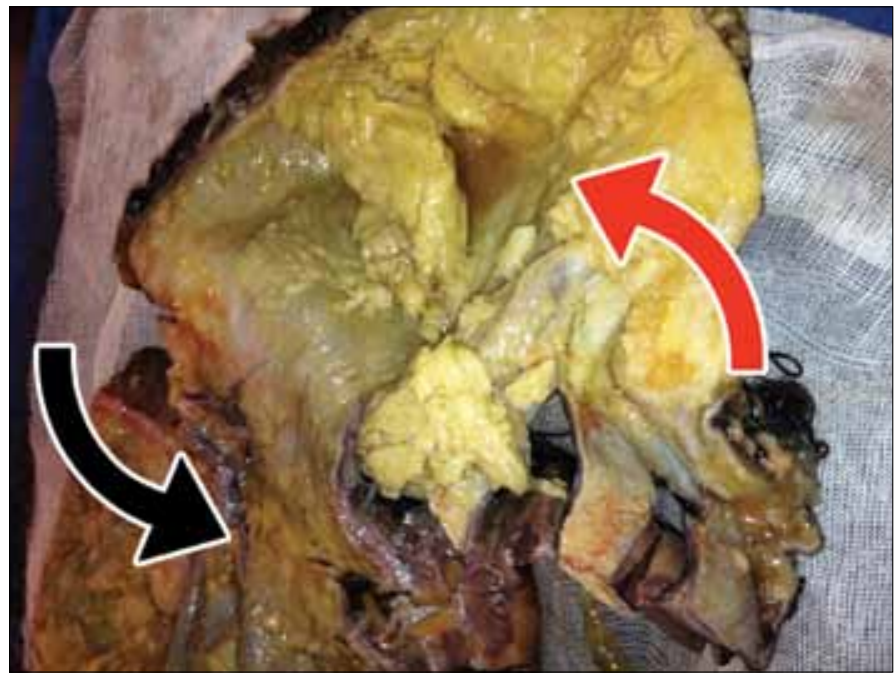

Figure 2. Macroscopic examination of pathological specimen

$10 \%$ of all renal hydatid disease (9). In our patient, hydaturia was not detected.

Laboratory tests might be helpful, but there is no immunological and serological test for the definitive diagnosis. Eosinophilia is determined in $25 \%$ of patients, but false-positive results may occur in different conditions, such as other parasitic infections and autoimmune diseases. Recently, the Casoni test has almost been abandoned because of its low accuracy. Even the complement fixation test and indirect hemagglutination test have higher accuracy diagnostic rates; a positive test does not completely confirm the diagnosis (10).

Radiological procedures are the most important tool in the diagnosis of hydatid cyst. Plain abdominal graphy and intravenous urography are historical tools, and today, diagnosis is dependent mainly on ultrasonography. Detection of daughter cysts and floating membrane are characteristic findings of hydatid cyst in ultrasonography. Cost-effectiveness and non-invasiveness are the other advantages, but the effectiveness of ultrasonography is based on the operator and changeable, as in our case. Daughter 
cysts are reported as solid lesions in our ultrasonography report. If there are any doubts, computed tomography or magnetic resonance imaging is performed. But, high-radiation dose CT can determine daughter cysts and calcification more easily when compared with USG (11). Parameters, such as size, location of hydatid cyst, and relationship with adjacent organs, are described more accurately with CT. MRI is an acceptable alternative to the CT scan. MRI detects a multiple or solitary lesion with high signal intensity, consisting of multiple thin walls and surrounded by a thick, hypointense rim.

The goal of the treatment is to remove all cyst contents in the kidney, and surgical modalities are the main treatment for renal hydatid cyst. Puncture-aspiration-injection-re-aspiration (PAIR) therapy is an alternative method for patients who can not tolerate operation or who do not wish to undergo operation, but its success is low, especially in multiocular cases (12). Partial nephrectomy, total cyst excition, and partial cystectomy are the kidney-sparing surgical therapies and are performed in $75 \%$ of all renal hydatid cyst cases. If the kidney is non-functional or is completely damaged by hydatid cyst, total nephrectomy is performed, as in our case (13). A laparoscopic approach is an alternative method but must be careful of risks of cyst rupture and dissemination.

\section{CONCLUSION}

In this case, we report an unusual presentation of Echinococcus granulosis. Particularly, in epidemic areas, as our country, physicians must have good knowledge about the disease and must be aware of its clinical presentations and complications.

Ethics Committee Approval: Ethics committee approval was not received due to the retrospective nature of this study.

Informed Consent: Written informed consent was obtained from patients who participated in this study.

Peer-review: Externally peer-reviewed.

Author Contributions: Concept - F.Ö.; Design - A.E.; Supervision - A.Y.M.; Funding - M.B., A.Y.B.; Materials - Ö.S.; Data Collection and/or Processing - F.Ö.; Analysis and/or Interpretation - F.Ö, A.E. ; Literature Review - F.Ö.; Writing - F.Ö., A.E, M.B.; Critical Review - A.Y.M., Ö.S.; Other - A.Y.B.

Conflict of Interest: No conflict of interest was declared by the authors.

Financial Disclosure: The authors declared that this study has received no financial support.
Etik Komite Onayı: Çalışmamızın retrospektif tasarımından dolayı etik komite onayı alınmamıştır.

Hasta Onamı: Yazılı hasta onamı bu çalışmaya katılan hastalardan alınmıştır

\section{Hakem Değerlendirmesi: Dış bağımsız.}

Yazar Katkıları: Fikir - F.Ö.; Tasarım - A.E.; Denetleme - A.Y.M.; Kaynaklar - M.B., A.Y.B.; Malzemeler - Ö.S.; Veri toplanması ve/ veya işlemesi - F.Ö.; Analiz ve/veya yorum - F.Ö., A.E.; Literatür taraması - F.Ö.; Yazıyı yazan - F.Ö., A.E., M.B.; Eleştirel Inceleme - A.Y.M., Ö.S.; Diğer - A.Y.B.

Çıkar Çatışması: Yazarlar çıkar çatışması bildirmemişlerdir.

Finansal Destek: Yazarlar bu çalışma için finansal destek almadıklarını beyan etmişlerdir.

\section{REFERENCES}

1. Cirenei A. Histopathology, clinical findings and treatment of renal hydatidosis. Ann Ital Chir 1997; 68: 275-84.

2. Zmerli S, Ayed M, Horchani A, Chami I, Elouakdi M, Ben Slama MR. Hydatid cyst of kidney: diagnosis and treatment. World J Surg 2001; 25: 68-74. [CrossRef]

3. Gögüş $C$, Safak $M$, Baltaci $S$, Turkölmez K. Isolated renal hydatidosis; exprience with 20 cases. J Urol 2003; 169: 186-9. [CrossRef]

4. Angulo JC, Sanchez-Chapado M, Diego A, Escribano J, Tamayo JC, Martin L. Renal echinococcosis: clinical study of 34 cases. J Urol 1997; 157: 787-94. [CrossRef]

5. Tsaroucha AK, Polychronidis AC, Lyrantzopoulos N, Pitiakoudis MS, Karayiannakis A, Manolas KJ, et al. Hydatid disease of the abdomen and other locations. World J Surg 2005; 29: 1161-5. [CrossRef]

6. Permenis P, Athanasopoulos A, Gyftopoulos K, Barbarias G. Primarily echinococcal disease of the kidney: the case for a more conservative approach. Int Urol and Neph 2001; 32: 609-13. [CrossRef]

7. Yuksel M, Demirpolat G, Sever A, Bakaris S, Bulbuloglu E, Elmas N. Hydatid disease involving some rare locations in the body: a pictorial essay. Korean J Radiol 2007; 8: 531-40. [CrossRef]

8. Kılcıler M, Bedir S, Erdemir F, Coban H, Sahan B, Ozgok Y. Isolated uniocular renal hydatid cyst: a rare diagnostic difficulty with simple cyst. Urol Int 2006; 77: 371-4. [CrossRef]

9. Horchani A, Nouria Y, Kbaier I, Attyaoui F, Zribi AS. Hydatid cyst of the kidney. A report of 147 controlled cases. Eur Urol 2000; 38: 461-7. [CrossRef]

10. Ameur A, Lezrek M, Boumdin H, Touiti D, Abbar M, Beddouch A . Hydatid cyst of the kidney based on a series 34 cases. Prog Urol 2002; 12: 409-14.

11. Ishimitsu DN, Saouaf R, Kallman C, Balzer BL. Best cases from the AFIP: renal hydatid disease. Radiographics 2010; 30: 334-7. [CrossRef]

12. Gabal Am, Khawaja FI, Mohammad GA. Modified PAIR technique for percutaneous treatment of high risk hydatid cyst. Cardiovasc Intervent Radiol 2005; 28: 200-8. [CrossRef]

13. Shah KJ, Ganpule AP, Desai MR. "Isolated renal hydatid cyst managed by laparoscopic transperitoneal nephrectomy," Indian J Urol 2009; 25: 531-3. [CrossRef] 